\title{
The Indian Ocean Tsunami Event: An Obvious Necessity for Research and Evaluation
}

\author{
Samuel J. Stratton, MD, MPH
}

University of California, Irvine College of Medicine, and The UCLA School of Public Health

\section{Correspondance:}

Samuel J. Stratton, MD, MPH

E-mail: strattos@uci.edu
The December 2004 Indian Ocean tsunami was a disaster of true international proportion. On one hand, the outpouring of relief resources by the world community is commendable and a tribute to all humanity. On the other hand, the tsunami demanded that disaster experts and researchers explore the international responses and preparations for such events. We can expect a steady flow of observational accounts and scientific papers that examine and evaluate the tsunami event from many perspectives. With the tsunami as the subject, the re-examination of current disaster concepts will be important, but the unique international character of the event should broaden the scope of disaster research exploration. This editorial is an attempt to present observations and develop a few hypotheses for research and evaluation of the tsunami event.

Considering the tsunami event, a number of disaster research issues come to mind:

1. What was the known risk for the occurrence of a tsunami before the event occurred?

2. How can the hazard of a tsunami and other such catastrophic events be evaluated in a meaningful way that will convince governments to allocate community resources to mitigate the damage from the event and enhance the responses to such potential events?

3. How could the effects of this specific tsunami event have been minimized?

4. What were the resources and efforts that had been made by governments and communities to prepare for a potential tsunami and were these efforts effective?

5. What could the international community have done prior to and after the tsunami to lessen the effects (impact) of the event?

Further, economic development throughout the world is an area for exploration. ${ }^{1}$ For example, would the impact of the tsunami have been as great if the hazard had been recognized and development of beach property been curtailed in favor of open beach, safety zones that would have served to blunt the physical impact of the tsunami? ${ }^{1}$

The issue of international participation in disaster preparation and response is important when considering a disaster as wide-spread as the Indian Ocean tsunami. The estimates of trillions of (US) dollars that will be required to return the Indian Ocean area to "normal" routines and to care for the persons displaced should be a strong indicator of the importance of prevention and preparation for disaster events. The budgets of governments helping in relief activities and the donation of funds to aid organizations are not limitless, and the resources allocated to the tsunami invariably will be drained from other international public health and social programs (opportunity costs). An important research question is what proportion of these world resources could have been saved if the tsunami hazard had been recognized and dealt with more effectively? 
The tsunami event illustrates the vulnerability of unaffected national governments and the international organizations to criticism from such an event. The international media were quick to criticize the "rich" nations and international organizations in their initial response to the event. What responsibility do international organizations have in helping local communities recognize and deal with disaster hazards? An important question is "How do international organizations pool world expertise to identify potential disaster hazards and prepare communities for a disaster occurrence?" Current efforts to develop rational, scientific methods of disaster hazard assessment should be strongly supported by the scientific community. Efforts to educate the world community in disaster prevention and initial damage mitigation would be much more resource effective than trillion dollar responses.

International organizations have an excellent opportunity to focus the attention that the tsunami has attracted to international efforts for damage mitigation and responses. Recent literature has explored methods that can be used by international stakeholders to organize for international dis- asters. The recent Gujarat, India earthquake initiated exploration of international organization and policy for worldwide disaster response. ${ }^{2}$ Further, the development of a horizontal organizational structure of the international disaster community as opposed to vertical organization recently has been explored in the disaster literature. ${ }^{3}$ Further exploration and debate of these ideas with application and evaluation is important to maximize the international response to disasters. Along with exploration of methods of organization, international organizations must have robust scientific and evaluation work that allows them to make rational actions.

The 2004 Indian Ocean tsunami was a true disaster that irreparably has affected a large portion of the world population. Hopefully, the horror of the disaster will alert the world disaster community to the importance of further developing international disaster damage mitigation and response. Effective evaluation and research of this distressing event is important to allow for potential prevention of future disasters.
References

1. Stephenson RS, DuFrane C: Disasters and development: Part 1. Relationships between disasters and development. Prehosp Disast Med 2002;17:110-115.
2. Bremer R: Policy development in disaster preparedness and management: Lessons learned from the January 2001 earthquake in Gujarat, India. Prebosp Disast Med 2003;18:372-384.

3. Burkle FM, Hayden R: The concept of assisted management of large-scale disasters by horizontal organizations. Prebosp Disast Med 2001;16:128-137.

\section{H.E.L.P. 2005 $\mathbf{H}_{\text {ealth }} \mathbf{E}_{\text {mergencies in }}$ $\mathbf{L}$ arge $\mathbf{P}_{\text {opulations }}$}

A three-week course to help participants meet health needs of refugees, internally displaced persons, and those affected by disasters and conflict, covering:

- planning, assessment, and evaluation

- assessing nutrition and organizing food distribution

- meeting needs for water, sanitation, shelter, and fuel

- establishing curative and preventive services

- control of communicable diseases in emergencies

- protection of women and other vulnerable groups

- collection and use of data to improve planning

- ethical concerns in response to conflicts

- reproductive health in emergencies

- humanitarian worker safety in the field

- applying International Humanitarian Law to protect populations at risk

11-29 July 2005

The Johns Hopkins University

Bloomberg School of Public Health, Baltimore, MD

Katrina Alston: (410) 955-3928

E-mail: helpcour@jhsph.edu

Co-sponsors: International Committee of the Red Cross-Geneva, American Red Cross, World Health Organization (WHO)/

Pan-American Health Organization (PAHO) 